\title{
Bons hábitos, ética e transdisciplinaridade
}

\begin{abstract}
"Somos o que fazemos repetidas vezes. A excelência, portanto, não é um ato, mas um hábito". Estas palavras compõem um dos ensinamentos de Aristóteles, considerado o pai de todas as ciências. Este filósofo grego (384-322 AC), que foi discípulo de Platão, e mais tarde tornou-se tutor de Alexandre "o Grande", influencia até hoje o pensamento ocidental nas atividades humanas. Pioneiro de vários campos da ciência, tendo praticamente inventado o pensamento lógico, enfatizou que o exercício dos bons hábitos torna as atitudes automaticamente boas, formatando-as em virtudes. A ética deve ser exercitada, bem como o esmero, o bom exercício técnico profissional, entre muitos anseios. O pensamento transdisciplinar, também deve ser um hábito. Se Aristóteles vivesse hoje, poderíamos dizer que exercia a transdisciplinaridade.

"A transdisciplinaridade diz respeito ao que está ao mesmo tempo entre as disciplinas, através das diferentes disciplinas e além de toda a disciplina." (NICOLESCU 1997)*.

Embora trabalhemos num segmento especializado, o exercício do conceito transdisciplinar passa a ser imprescindivel para oferecer um tratamento adequado aos nossos pacientes.
\end{abstract}

Nesta edição, um exercício transdisciplinar é apresentado na seção entrevista, que tem como convidado o professor Paulo Conti, versando sobre as Disfunções Temporomandibulares (DTMs) e as Dores Orofaciais (DOFs). A preocupação ética e do envolvimento de outras áreas de atuação, manifestadas nas perguntas e respostas deste texto, apresentando uma ampla sustentação científica, associada à clareza e à objetividade, nos fez escolhê-lo como "selecionado pelo editor".

Este tema também é explorado por um estudo de prevalência destes problemas em crianças, realizado em Araçatuba (UNESP).

O desenvolvimento tecnológico tem melhorado os recursos de imagens, dos aparelhos, recursos de ancoragem como os mini-parafusos e miniplacas, e também avançando a passos largos no campo da pesquisa. Particularmente, o método dos elementos finitos tem poupado testes exaustivos em seres humanos ou animais. Esclarecimentos básicos sobre este método, bem como sua ampla abrangência, são retratados pelo artigo de Lotti e colaboradores, que também já publicaram nesta revista um trabalho aplicando os elementos finitos.
No quesito de métodos de diagnóstico, e também para pesquisas, são avaliados um programa cefalométrico computadorizado, uma planilha digital para o cálculo da discrepância dentária de Bolton, além de um método de mensuração das angulações e inclinações coronárias em modelos de gesso.

Quando elegemos o procedimento de expansão rápida da maxila, muitas vezes torna-se imprevisível a abertura da sutura palatina mediana. Um estudo piloto, realizado na Universidade de Itaúna-MG, questiona o uso da referência de maturidade esquelética como parâmetro deste prognóstico. Ainda, colocando o método de rinometria acústica à prova, Cappellette Jr. e colaboradores apresentam os incrementos, em curto prazo, da cavidade nasal após o procedimento de disjunção palatina (expansão rápida da maxila) em crianças respiradoras bucais.

Brant e Siqueira corroboram muitos trabalhos da literatura ao apresentarem uma comparação de perfis cefalométricos pós-tratamento de casos ortodônticos que receberam ou não exodontias de 4 pré-molares.

Conceitos do acompanhamento fonoaudiológico pós-cirúrgico, a importância da prevenção de cáries e doença periodontal, bem como a responsabilidade civil do ortodontista são abrangidos também nesta edição.

Robert Murray Ricketts, um expoente norte-americano da Ortodontia, deixou um legado técnico-científico. Nasceu em 1920 e faleceu há 3 anos e, sem dúvida, foi um praticante de bons hábitos, que lhe renderam várias virtudes, entre elas a ortodôntica. No segmento Tópico Especial, o prof. Mário Sérgio Duarte discorre sobre o aparelho quadrihélice (Quad-helix), que foi uma das contribuições do Dr. Ricketts, apresentando um texto ricamente ilustrado.

Apresentamos aos leitores uma ótima oportunidade para o exercício de alguns dos bons hábitos (ao menos os diretamente ligados à nossa profissão). Que todos possam manifestar virtudes como a excelência, a ética e a transdisciplinaridade!!

Boa leitura.

Adilson Luiz Ramos

*NICOLESCU, B. Evolução Transdisciplinar da Universidade Projeto CIRET UNESCO, 1997. 